Copyright (C) 2018 by Academic Publishing House Researcher

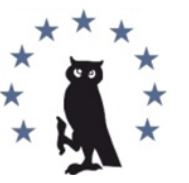

Published in the Russian Federation

European Researcher. Series A

Has been issued since 2010.

ISSN 2219-8229

E-ISSN 2224-0136

2018, 9(3): 194-202

DOI: $10.13187 /$ er.2018.3.194

www.erjournal.ru

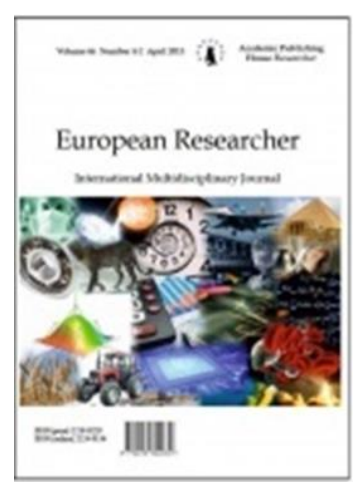

\title{
Sensationalism in Reporting on Domestic Violence
}

\author{
Marija Boranijašević ${ }^{a}$, * \\ a Business School of Applied Studies Blace, the Republic of Serbia
}

\begin{abstract}
From the point of view of communication science, the author in the paper analyzes the way domestic violence is reported in the media of mass communication, especially daily press. Taking into account the formulated problem and the set goal of research, which is analyzing the way in which domestic violence is reported in newspaper articles, the used methods in this research are the methods of analysis and synthesis as basic scientific methods, and the case study method as a method for data collection. The sample of research consists of articles dealing with domestic violence in five different national daily newspapers during a period of one week, these newspapers being: "Politika", "Večernje novosti", "Blic", "Kurir" and "Alo!". A review is done on the way sensationalism is built around the stories dealing with domestic violence, very often ending fatally. Certain attention is also devoted to the role of the police in these matters and the image of it that is created in newspaper articles concerning domestic violence.
\end{abstract}

Keywords: sensationalism, domestic violence, mass media, daily newspapers, reporting, the police.

\section{Introduction}

The media of mass communication are commonly considered to be the four socially most present and most influential mass media: the press, film, radio and television. "On the basis of the technological procedure of substancialization of information in the form of a message it is possible to differentiate between printed and electronic media of mass communication" (Miletić, Miletić, 2012: 183).

Newspapers are the most widely spread printed media of mass communication which represent a synonym for press. "Journalism was born and developed in them together with numerous forms of launching political, economic and cultural ideas and interests" (Pavlović, Aleksić, 2011: 187). Taking into account the dynamics of publishing, there are two different kinds of newspapers: daily newspapers and periodical newspapers. Concerning the targeted reading audience, newspapers could be divided into local, national and multinational. The attention in the paper is be devoted to daily newspapers, since the sample of research consists of five different national daily newspapers.

In the history of journalism it is stated that the first newspapers appeared in Rome in the year of $59 \mathrm{BC}$ and they existed in the Roman Empire up to the third century AD. The first newspapers were wall newspapers, white wooden boards with black letters. Historians also mention handwritten newspapers that were sold in the squares of Venice from $13^{\text {th }}$ century, and

\footnotetext{
* Corresponding author

E-mail addresses: marijaboranijasevic@yahoo.com (M. Boranijašević)
} 
later in other Italian and European towns. The first printed newspaper appeared at the beginning of $17^{\text {th }}$ century. "The early newspaper was marked by its regular appearance, commercial basis (openly for sale), multiple purpose (for information record, advertising, diversion and gossip) and public or open character" (McQuail, 1994: 13). The first newspaper in the Serbian language "Serbskija povsednevnija novini" was published in Vienna in 1791, while in Serbia "Novine srbske" was printed first in Kragujevac in 1834. Newspaper became a medium of mass communication in $19^{\text {th }}$ century. The key moment was the appearance of the so-called penny-journal in the thirties of $19^{\text {th }}$ century which caused the development of the so-called yellow press which uses the low cost and sensationalistic approach to attract readers' attention. In 1901 the Daily Mail was the first newspaper to overcome the printing of one million newspapers (Miletić, Miletić, 2012: 219). "The aim is clear: to make as much profit as possible through a large circulation and expensive advertising space. A dull public and political debate is replaced by fun and sensationalism in the newspapers" (Radojković, Miletić, 2008: 115). The "yellow press" is built upon sensationalistic reporting on crimes, scandals, gossip, divorce affairs, adultery, accidents, violence etc. The articles are usually accompanied by very realistic photographs, sometimes blurred so that faces could not be recognized (in case of children abuse, for instance). However, "yellow press has created the institution of a daily newspaper as the most influential and widespread mass medium for a long time" (Bogdanić, 1996: 73). At the same time there appear "more serious and more objective" newspapers like the Times in the USA. At the end of the $19^{\text {th }}$ century the yellow press loses the battle against the newspapers such as the Times, while its role is later taken over by other sensationalistic weekly newspapers and tabloids (Bogdanić, 1996: 73).

While newspapers are supposed to provide the readers with objective, relevant information, unfortunately very often that is not the case. In many circumstances the information launched in the published newspapers is only partially true. Those are usually the facts taken out of context and used to build up sensationalism on, not to mention the cases when the published news could be a complete fabrication.

Information

Let us try to define information in the first place. In the literature it is stated that even more than a hundred and twenty different definitions of information could be found. "Such abundance is a logical consequence of a large number of possible interpretations of the same phenomenon, but also of the fact that neither of these definitions has been universally accepted" (Radojković, Đorđević, 2005: 29).

Nevertheless, we shall state some mostly cited definitions of information. For a start, Zorica Tomic states that "the term INFORMATION originates from the Latin language and means to SHAPE, FORM, i.e. PRESENT something” (Tomić, 2003: 33-34). The author proceeds to explain that "the term notification originates from the same root as the words news, consciousness, unconsciousness, conscience, history, command, narration (narrative), since they have the same root in the Old Slavic word VED, which means knowledge. To inform, in that sense, means to tell something to another person so that they can know it as well (notification) (Tomić, 2003: 34).

Toma Đorđević defines information as "practically acquired knowledge previously not known in the human experience and communicated by linguistic or non-linguistic systems of meaning so that it can be exchanged among the subjects of communicative acts as symbolically mediated experience significant for the direction and efficiency of human practice (Đorđević, 1979: 16).

Kathleen Reardon states that earlier models of communication considered information to be some kind of an object which is transferred from one person to another using a channel, e.g. interpersonal channel or a mass medium. According to such a model of communication, if there is no interference and the sender of the message possesses enough of a communication skill, the receiver of the information will understand the meaning of the message. According to the newer models of communication, people select information on the basis of their needs and wishes, so the meanings they are to get out of them are connected to the previous experience, our needs and expectations (Reardon, 1998: 15-16).

Jasna Janićijević claims that "in each communication, regardless its goals and intentions, there is some information. Via information we become aware of something, understand things and realize what they represent. Information message is something that the very receiver has to interpret" (Janićijević, 2000: 25). 
In the end, here is probably the simplest and clearest of all the definitions: "Information in communication science is an announcement about a special event in some system, which means an announcement about the difference as compared with the previous condition of the system" (Mandić, 2003: 18).

This information, or announcement, must therefore be as objective as possible. Or it should at least be so. However we are witnesses of common non-objective reporting, and all due to attracting more readers by building up sensationalism around everyday stories, very often using this unpopular technique on some very delicate topics such as domestic violence and alike. This way we cannot be sure which part of the launched story is true and which one is built upon since mass media represent "a distinguished set of activities regarding their having a primary, not derived function to designate or construct reality ... Mass media are huge contributors to our perception both on the basis of information they contain and their interpretation of this information" (Lorimer, 1998: 45). Consequently, the media such as press can either report on reality or even create it. Therefore we can hardly distinguish between the two, while the motive for this reality creation is attracting more readers, meaning selling more newspapers, meaning increasing their profit. This could be called manipulation of the reading audience since some delicate topics are misused by creating sensationalism in order to sell more. "Serbian tabloids have a distinctive tabloid content - sensationalistic writing about private lives of celebrities" (Domazet, 2008: 151). It seems that freedom of speech in Serbia is sometimes misused. Articles on various topics are published. They are written in a way to cause different emotions with readers such as "fear, rage, anger, vulnerability or unhealthy curiosity, which constantly asks for the same content in larger amounts" (Domazet, 2008: 153). Readers therefore seek for more articles with topics like these, lured by this tone of sensationalism. Domestic violence is one of the most present topics of this kind being written about not only in tabloids, but in daily newspapers that are considered to be the objective ones. However, certain difference can be noticed in the way these topics are dealt with in different daily newspapers in Serbia. Some of them try to report objectively on the events that have happened, while in the others sensationalism is very present and overemphasized. The analysis that follows has the aim to present the difference that exists in the way various national newspapers deal with the topics of domestic violence.

\section{Methodology of research}

Taking into consideration the formulated problem and the set goal of research which is reflected in analyzing the newspaper articles dealing with domestic violence, devoting special attention to sensationalism built upon those stories, in this research methods of analysis and synthesis have been used as basic scientific methods and the study case method as a method for data collection.

The sample for analysis in this paper is represented by the articles published in the national daily newspapers. The sample consists of five different national daily newspapers published in the period of one week, from $17^{\text {th }}$ April till $23^{\text {rd }}$ April 2018, those newspapers being: "Politika", "Večernje novosti”, "Blic", "Kurir” and “Alo!".

The newspaper articles dealing with domestic violence are analyzed from the point of view of the way these topics are dealt with in these articles. In some cases these events are objectively reported, while in others they are used in order to make sensationalistic newspaper headlines in order to attract more readers. Very often human destinies are misused for the sake of achieving more profit. When compared, the same stories in different daily newspapers contain information which differs more or less.

What is also interesting is that the very same stories are sometimes repeated from day to day, with very little variation in them. The information is still the same, sometimes with some new aspect being added to it, or just the same story being told in different words. This kind of reporting could especially be noticed in cases of reporting on celebrity domestic violence, which is overemphasized and repeated all over again in the newspaper articles for a longer period of time. The analyzed sample proves this point. In some cases the same story had been dealt with during the whole week, which was the research period, and there is a good chance of their being discussed in the days to follow which are no longer the subject of research in this paper. 


\section{Results}

The analysis starts start with the daily newspaper "Politika" concerning the tradition of publication, it being the oldest daily national newspaper in the sample, and also the image of it as being an objective medium not prone to "yellow" topics and sensationalism. The first glance at the articles dealing with the researched topic in the paper proves this assumption.

In the $17^{\text {th }}$ April 2018 paper there is an article on domestic violence where celebrities are involved. It is a story about a pop star Nataša Bekvalac who was abused and beaten by her husband only a month after she had given birth to their baby daughter. However, there is nothing sensationalistic in this article, quite the opposite. The journalist is emphasizing sensationalism that has been built around this event in other daily newspapers and it has been carrying on. The title of the article is "When Victims of Violence Become a Target of Media Torture (Politika, 2018: 7). There is a photo of the singer from her professional period, but none from this mentioned event which had happened three days before. The journalist notes that this event has become the latest sensationalistic news in most of the tabloid papers, putting aside many relevant events from political, social and cultural spheres in Serbia today. Moreover, those newspapers have been competing in publishing more and more photos of the singer with bruises, completed with comments of the members of the spouses' families, their ex partners etc., and all this with one single goal - making sensation out of a violent act. The worst of all are comments like "What has she done to provoke such a reaction?", comments of people trying to justify the behavior of the tyrant and looking for the guilt on the victim's part. It is stated that every ten days one woman in Serbia is killed by her father, husband or son. Vesna Stanojevic, a coordinator of the Safe House for Women, states that reporting on domestic violence in the families of celebrities is very often unethical, banal and unprofessional, emphasizing the fact that a possibility of a tragic end is very often ignored. She warns that domestic violence has been on the rise since the beginning of the year - as many as 18 women have been killed (Politika: 7). The First Basic Court in Belgrade ordered Luka Lazukić, the husband, to be removed from the apartment up to 30 days and issued a restraining order the day before, all this in accordance with the new Law on Prevention of Domestic Violence. The prosecution is still waiting for the criminal charges on the part of the police, after which a hearing of Lazukić, Bekvalac and the babysitter who was present in the apartment at the time will be held. The Chairman of the Assembly Committee for Human and Minority Rights Meho Omerović has praised a fast reaction of the police and court in this case, expressing his hope that all the victims of domestic violence will be treated in the same manner in the future, regardless the fact whether they are celebrities or not. On the other hand, celebrities also have a right to protection of their privacy and basic human rights (Politika: 7). The bottom line is that mass media should not use situations like this for making sensationalistic headlines and attracting readers, but report objectively.

A good example of a non-biased, objective and realistic reporting on domestic violence is found in the same newspaper. A tragedy happened in Kula when a man, Blagoje B. (61), murdered a woman, Rada Đ. (50), and then killed himself. The Ministry of Internal Affairs has reported that the investigation had been completed and that the police are working on finding out all the details concerning this case. The bodies of the two have been sent to autopsy, the man's body with a chest wound and the woman's body with a wound in her head. Only three days before, a similar crime happened. In Ostružnica a man murdered his unmarried wife and then killed himself. Although the new Law on Prevention of Domestic Violence has been in use since $1^{\text {st }}$ June 2017, unfortunately there has been a rise in the number of crimes over women from the beginning of this year. Eight women were killed in the first two months in domestic and partner violence, while during last year 26 women were killed (Politika: 9).

There is another article dealing with domestic violence with a fatal end. A folk singer Jelena Marjanović was killed on $2^{\text {nd }}$ April 2016. Her husband has been the main suspect. However, the case has not been terminated yet, and there have been appearing new details in the investigation which are reported in a very sensationalistic way. This event was very present in the mass media two years ago when the crime happened. However, it is still present now, after two years from the murder. A journalist Mladen Mijatović has even written a novel with a title "The Murder of Jelena Marjanovic". This mysterious criminal case has become a sensation that goes on and on. In this paper there is also an article concerning the new details in this case, which seem almost irrelevant. Nevertheless, they make way for continuation of a sensationalistic reporting on the murder of this poor woman. 
In "Politika" issued on $18^{\text {th }}$ April 2018, there is an article with a title "A Tragic Balance of Domestic Violence" (Politika: 7). Statistics about domestic violence say that every third woman killed during 2017 had previously been reporting the violence to the police, states Vanja Macanović, a lawyer of the Autonomous Women's Center. A case of Jelena G. from Požarevac is mentioned. The woman was killed by her husband after the police officer who had been sent on field after their family fight estimated that there was no risk for the victim and sent the spouses to the Center for Social Work. The police officer was punished and fired from work. However, that cannot change the fact that a woman has been murdered. It is noted that there are great professionals in the system but also those who do not do their job right. For instance, in Belgrade only in four out of 17 police stations police officers have been designated to deal with domestic violence exclusively, while the situation in other Serbian towns is even worse (Politika: 1,7 ).

In "Politika" from $19^{\text {th }}$ April 2018 there is a continuation of the Bekvalac story; a very concise though. Luka Lazukić has initiated criminal charges against his wife for false reporting on domestic violence. Also criminal charges for the criminal act of domestic violence against Lazukić have been initiated by the police. The hearing of Lazukić, Bekvalac and the babysitter has been scheduled for $24^{\text {th }}$ April. It is a short informative article with no sensationalism in it (Politika: 7).

In "Politika" issued on $20^{\text {th }}$ April 2018 there is an article stating that the higher prosecutor's office has issued an indictment against Siniša Radovančev with residence in Pančevo for murdering his unmarried wife Biljana Mijatovic in November last year. He is being held in custody and a trial is expected soon. He had murdered his wife, stabbing her in the chest, just about twenty days after they got a baby. The victim's eight-year-old daughter from her previous marriage and the baby are taken care of by the Center for Social Work "Solidarnost" Pančevo (Politika: 7). This time too, there was no sensationalism being built upon the reported domestic violence. The following three issues of "Politika", on $21^{\text {st }}$ April, $22^{\text {nd }}$ April and $23^{\text {rd }}$ April 2018, do not contain any articles on domestic violence.

In "Večernje novosti" issued on $17^{\text {th }}$ April 2018 there is a short article on domestic violence about a son, Vladan P. (50), who had brutally beaten his father Miljko P. (71) and broke him three ribs. While waiting to serve a sentence, the son beat his father again, since they still lived in the same house. This case should alarm the public and competent authorities to speed up the procedure of sentencing the perpetrator of violence or to keep them in custody till sentenced. As we can see, these two people were living together although the son had hurt the father badly before. The violence could have been prevented in case the son had been removed from the family house after the violent act. This short article offers facts only. There is no sensationalism present in it. However, that could not be said for the other article about the previously mentioned case of Jelena Marjanović. The text is several times larger, with a few photos from the crime scene. Let us only mention that the crime happened two years ago, not to mention that the article is about some seemingly irrelevant details like a short message the victim had sent to the doctor before her death. The doctor was summoned to hearing. Namely, the Higher Court had asked for more details in order to investigate further (Večernje novosti: 12). So this case goes on, as does the sensationalistic reporting on it. There are two reasons for this: an unresolved, mysterious case and, moreover, the case of a celebrity. Unfortunately, these cases are prone to sensationalism.

In the same paper there is an article about the murder of Rada Đukic (50), now with a full name, by Blagoje Bratić (61), also a full name. If we compare this article to the one published in "Politika" about the same event, this one is much more sensationalistic, starting from the effective headline "A Bullet in the Head for a Woman, Two in the Chest for Himself", not to mention the stories of neighbors, friends and colleagues speculating on the love affair between the two people involved (Večernje novosti: 13).

Another shocking article in the same paper states that a ten-year-old girl has been sexually abused by her father, J.Š. (43). This act was reported by her elder sister. The two of them lived with their father, two of their siblings with their mother after the divorce, while the four out of eight children were in foster families. The Center for Social Work in Novi Sad could not provide any information since all the information about personal and family matters that they find out in the Center are confidential (Večernje novosti: 13).

There are also two short articles reporting on domestic violence. Two people, D. I. (26) from Vranje and S. H. (29) from Bujanovac were arrested since suspected to have performed domestic violence. D. I. attacked his brother and his unmarried wife, while S. H. attacked and injured his father with a sharp object. Both of them have been kept in custody and are to be initiated criminal 
charges against. A more tragic ending happened in Rožaje where Ernes Škrijelj (47) murdered his brother Mersad (37). In the first case only initials are used, while in the other full names (Večernje novosti: 13). However, the articles are very short, informative and not at all sensationalistic. This leads us to the conclusion that sensationalistic reporting is reserved for celebrities or cases full of intrigue like love affairs and similar.

In that manner continues the story of the murder of Rada Đukic in the $18^{\text {th }}$ April edition. This time the article if full of assumptions that the murderer could have been a third party since it is unlikely that a person would have shot oneself twice (Večernje novosti: 12). Unlike these speculations, there is another short article containing the information that the police in Vranje have arrested S. S. (53) who is suspected to have attacked his mother. The person has been kept in custody and is to be initiated criminal charges against (Večernje novosti: 13).

In the same issue there is a continuation of the story of a molested girl. They report that the mother has also been suspected of child abuse. The children had been neglected, and that is the reason why four of them are already in foster families. Besides this, a part of the article is identical to the one published the day before.

Another story about domestic violence appeared in "Večernje novosti" issued on $19^{\text {th }}$ April 2018 about Dragan Marković (66), an alchoholic, who fiercely murdered his mother Slobodanka Marković (94) in the village Radoševo near Arilje. Firstly, he said that she had died naturally, but since he did not allow anyone to see her body, his relatives called the police. Since there were bruises on the body of the dead woman, they ordered an autopsy which proved that she had been murdered, i.e. she had been beaten till death. Dragan has been retained for 48 hours and is going to be prosecuted (Večernje novosti: 10). This event seems to be reported objectively, accompanied with a photo from the funeral with a coffin in it, though.

The $20^{\text {th }}$ April issue of "Večernje novosti" brings new stories of domestic violence. One of them ended fatally when Dejan Stanković (37) cut his grandmother's throat. Zorka Stanković was 85. The two of them had lived together in the village Kovačevac near Mladenovac. The murderer is said to have had psychological problems which got even worse after his mother's death last year. After the crime he called the police and told them what he had done. He did not resist the arrest. After 48 hours of retention, hearing will be held in the prosecutor's office. His mental health will also be assessed (Večernje novosti: 12).

Another shocking story of a child abuse appeared in the same issue. Actually the stepfather, Ljubiša K. (71), had been sexually abusing his stepdaughter for five years before she had enough courage to report that to the police. It all started when she was only 9 years old. Moreover, he has made his stepdaughter be sexually involved with N. M. (71) for money. N. M. confessed the crime and he was sentenced to one year in prison, while Ljubiša $\mathrm{K}$. was sent to prison hospital to be investigated. And what is even more shocking is the fact that the girl's mother stated that she had suspected that something was wrong. However she did nothing (Večernje novosti: 13)!

In the $21^{\text {st }}$ April issue of "Večernje novosti" there is only a short article about Dejan Stanković who has violently murdered his grandmother with the information that he has decided to remain silent in the prosecutor's office, although he himself had called the police and did not resist the arrest (Večernje novosti: 12).

The $22^{\text {nd }}$ April and $23^{\text {rd }}$ April editions of "Večernje novosti" do not contain any articles on domestic violence. What is also interesting is the fact that these two daily newspapers report on different cases of domestic violence. "Večernje novosti" does not even mention the case of Nataša Bekvalac, while it offers some other stories not mentioned in "Politika".

"Blic" issued on $17^{\text {th }}$ April 2018 presents the same story about the murder of Jelena Marjanović. It is still about the doctor who Jelena sent her last short message to about some prescriptions for her mother (Blic, 2018: 16). And it is the same old story retold again.

There is also an article about the father abuser previously mentioned, although this time the information in the article is different. Namely, in this paper the father is accused of sexual abuse of both son (12) and daughter (10) who lived with him, while in "Večernje novosti" it was two daughters living with him and he abused the younger one (Blic, 2018: 26). As we can notice it is a completely different story being told in two daily national newspapers.

Sensational reporting is continued in the case of Rada Đukic who was allegedly killed by her lover and employer after her attempt to reconcile with her husband. In one version of this event her son found the dead bodies with a policeman friend, while this time it was the company's doorman 
who found the bodies (Blic, 2018: 26-27). It is the second time that information in the articles differs. It seems that sensationalism in reporting is much more important than checking the credibility of the information. Do not the readers have a right to true information? How can they tell which one is true?

More sensationalism is noticed in reporting about the case of Nataša Bekvalac. In this paper there are two full pages about his event. There are speculations about the motive for Lazukić's beating his wife like the one that she was making a scene about certain "love" messages found in his phone after which they fought, or mentioning that he had been seen with two girls in town that night (Blic, 2018: 28-29). The whole two pages are speculations on their personal affairs. The only objectively stated part of the story is the one that criminal charges have been initiated against Lazukic in the procedure according to the new Law on Prevention of Domestic Violence, so he had to leave the apartment instantly.

The $18^{\text {th }}$ April issue continues in the same manner - two more pages about the physical abuse of Nataša Bekvalac with huge photos documenting bruises and cuts on her face and body. The only new information offered is the one that Luka Lazukić has initiated criminal charges against her for slander, claiming that he has not beaten her at all (Blic, 2018: 20-21). Sensationalistic continuation of Jelena Marjanovic story is also there, stating that out of fourteen witnesses, the key witness could be a bicyclist from Borča who must have seen the late Jelena and her husband minutes before the murder happened (Blic, 2018: 16-17). The case of Rada Đukic is present again, the journalist now speculating on the two shots in the alleged murderer's chest as being possible, but suspicious (Blic, 2018: 17). There is another continuation of the "father monster" story. This time, the mother of the molested children states that it has never crossed her mind that her ex-husband could have sexually abused their children. The two children that lived with her have been taken away from her due to neglect and criminal charges for neglecting children have been initiated against her (Blic, 2018: 18-19).

The Bekvalac saga continues in the $19^{\text {th }}$ April issue with the same gigantic pictures of the singer with bruises and the same story being retold without any new information in it on another two pages (Blic, 2018: 18-19). This is a perfect example of sensationalistic reporting, using the name of a celebrity and the details of her private life in order to attract more readers. Unlike this event, there is another article, already mentioned before, about a son who brutally murdered his old mother with no sensationalism in it (Blic, 2018: 17).

In the $20^{\text {th }}$ April issue another two pages about Nataša Bekvalac appeared outrageously with the same two photos as in the previous two editions and the same old story retold. Similar situation is seen in Jelena Marjanović story. The case of Nataša Bekvalac is repeated in the $21^{\text {st }}$ April issue, just to be continued in the $22^{\text {nd }}$ April issue with an interview with Nataša's father with a lot of private details again. The story continues in the $23^{\text {rd }}$ April edition in which the whole event is repeated again, stating that this act of violence will be legally prosecuted (Blic, 2018: 21). This is where our sample ends. However, it is highly likely that the Bekvalac story will not end here, judging from the sample analyzed, since it was present in every issue of "Blic" during the week of the sample period. The situation is similar to Jelena Marjanović's murder, the story of which is also present in the $23^{\text {rd }}$ April issue, now stating that the late singer's and the alleged murderer's sevenyear-old daughter is going to be the last witness in the case (Blic, 2018: 14).

The $17^{\text {th }}$ April issue of "Kurir" offers sensationalistic reporting on the previously mentioned cases of Jelena Marjanović, the "monster father" abuser and Rada Đukić (this time there are two bullets in Rada's body, one in the head and the other in the back, while one of the three ended in Batrić's chest while two only scratched him), while in the case of Nataša Bekvalac there are sensationalistic details about the spouses' fight for the property (Kurir, 2018: 12, 13, 16, 17)!

The $18^{\text {th }}$ April issue continues in the same manner, with another two pages about Nataša Bekvalac with very little new information except for the fact that the singer will claim full custody over their daughter. All the rest is retelling the story, as well as in the $19^{\text {th }}$ April edition in which another two pages appeared, full of gossip and other irrelevant private information and speculations with the very aim of building up sensationalism around this tragic event. The saga is present in the $20^{\text {th }}$ April and $21^{\text {st }}$ April editions with the same dose of sensationalism, as well as in the ones issued on $22^{\text {nd }}$ April and $23^{\text {rd }}$ April 2018, while stories about other events of domestic violence that appear in this paper, and were previously mentioned, are shortly reported. 
Sensationalistic reporting is even more emphasized in "Alo!". Speculations on the details of the love affair of the victim of a murder, Rada Đukić, or alleged adultery of Luka Lazukić are present in the articles, as well as Lazukić's insults directed to his wife. In all the seven editions which represent the sample of research, the story of Nataša Bekvalac is present with a lot of detailed discussion about irrelevant topics not connected to the event of violence, while other stories of domestic violence are shortly reported.

\section{Conclusion}

After the presented analysis, a conclusion that can be drawn is that domestic violence is differently reported depending on the daily newspaper in which it appears and depending on the fact who the victims or perpetrators of the violence are.

As the analysis shows, the most sensationalism is built upon the stories of domestic violence involving celebrities, in this case Jelena Marjanović, and especially Nataša Bekvalac. The only daily newspaper that condemned this pattern of reporting is "Politika". All the rest, except for "Večernje novosti" (no reporting at all), reported on it in a more or less sensationalistic manner. The journalists keep using the fact that the victim of violence is a celebrity in a very ugly manner in order to make sensationalistic headlines and attract more readers, not to mention irrelevant details being brought and discussions on various private matters. A celebrity or not, a person is entitled to protection of their privacy.

In most of the articles analyzed, the emphasis is put on irrelevant details for the sake of sensationalism, putting aside the violent act itself and the consequences of it. Unlike this kind of reporting, newspaper articles could be used in a more positive manner in order to stress the fact that domestic violence is more and more present in everyday lives of citizens of the Republic of Serbia, their being celebrities or not. Not much is told about concrete actions that are taken when domestic violence takes place, starting from the intervention of an authorized police officer, removal from apartment to prosecuting the perpetrator, and all this in order to make space for sensationalistic reporting on irrelevant, gossipy details.

In some cases it is mentioned that the victim of domestic violence had reported on the repeated violent acts before the fatal one happened. However, violence was repeated. Besides, according to the Law on Prevention of Domestic Violence everyone is obliged to report on domestic violence if being a witness of it. Sometimes closing your eyes before it could have a fatal result. Therefore there is a need of raising public awareness on this matter and realizing that it is our obligation to act and call the police next time we happen to be witnesses of domestic violence.

\section{References}

Bogdanić, 2005 - Bogdanić, A. (1996). Komunikologija, vodeća paradigma (Communication Science, the Leading Paradigm). Beograd: Čigoja štampa.

Domazet, 2008 - Domazet, $S$. (2008). Tabloidno društvo, tabloidni mediji tabloidna svest (Tabloid Society, Tabloid Media and Tabloid Conscience). U (in): Knjiga za medije - mediji za knjigu (A Book for Media - Media for a Book). Priredila (edited by) Divna Vuksanović. Beograd: Clio, pp. 150-155.

Đorđević, 1979 - Đorđević, T. (1979). Teorija informacija, Teorija masovnih komunikacija (The Theory of Information, the Theory of Mass Communication). Ljubljana, Beograd: Partizanska knjiga, OOUR Izdavačko publicistička delatnost.

Janićijević, 2000 - Janićijević, J. (2000). Komunikacija i kultura sa uvodom u semiotička istraživanja (Communication and Culture with an Introduction into Semiotic Research). Sremski Karlovci, Novi Sad: Izdavačka knjižarnica Zorana Stojanovića.

Lorimer, 1998 - Lorimer, R. (1998). Masovne komunikacije (Mass Communication). Beograd: Clio.

Mandić, 2003 - Mandić, T. (2003). Komunikologija, psihologija komunikacije (Communication Science, the Psychology of Communication). Beograd: Clio.

McQuail, 1994 - McQuail, D. (1994). Mass Communication Theory, an Introduction. London, Thousand Oaks, New Delhi: SAGE Publications.

Miletić, Miletić, 2012 - Miletić, M., Miletić, N. (2012). Komunikološki leksikon (Communication Science Lexicon). Beograd: Megatrend univerzitet. 
Pavlović, Aleksić, 2011 - Pavlović, M., Aleksić, M. (2011). Odnosi s javnošću (Public Relations). Beograd: Megatrend univerzitet.

Radojković, Đorđević, 2005 - Radojković, M., Đorđević, T. (2005). Osnove komunikologije (The Basics of Communication Science). Beograd: Fakultet političkih nauka, Čigoja štampa.

Radojković, Miletić, 2008 - Radojković, M., Miletić, M. (2008). Komuniciranje, mediji i društvo (Communication, Media and Society). Beograd: Učiteljski fakultet, Univerzitet u Beogradu.

Reardon, 1998 - Reardon, K. K. (1998). Interpersonalna komunikacija, Gdje se misli susreću (Interpersonal Communication, Where Thoughts Meet). Zagreb: Alinea. štampa.

Tomić, 2003 - Tomić, Z. (2003). Komunikologija (Communication Science). Beograd: Čigoja

Politika, 2018 - Politika: $17^{\text {th }}$ April 2018, $18^{\text {th }}$ April 2018, 19 ${\text { April 2018, } 20^{\text {th }} \text { April 2018, 21 }}^{\text {st }}$ April 2018, 22 ${ }^{\text {nd }}$ April 2018, $23^{\text {rd }}$ April 2018.

Večernje novosti, 2018 - Večernje novosti: $17^{\text {th }}$ April 2018, 18 $8^{\text {th }}$ April 2018, $19^{\text {th }}$ April 2018, $20^{\text {th }}$ April 2018, 21 ${ }^{\text {st }}$ April 2018, $22^{\text {nd }}$ April 2018, $23^{\text {rd }}$ April 2018.

Alo, 2018 - Alo!: $17^{\text {th }}$ April 2018, $18^{\text {th }}$ April 2018, $19^{\text {th }}$ April 2018, 20 th $^{\text {th }}$ April 2018, 21 ${ }^{\text {st }}$ April 2018, $22^{\text {nd }}$ April 2018, $23^{\text {rd }}$ April 2018.

Blic, 2018 - Blic: $17^{\text {th }}$ April 2018, $18^{\text {th }}$ April 2018, 19 $9^{\text {th }}$ April 2018, 20 th $^{\text {th }}$ April 2018, 21 ${ }^{\text {st }}$ April 2018, $22^{\text {nd }}$ April 2018, $23^{\text {rd }}$ April 2018.

Kurir, 2018 - Kurir: $17^{\text {th }}$ April 2018, 18 $8^{\text {th }}$ April 2018, 19 th $^{\text {th }}$ April 2018, 20 ${ }^{\text {th }}$ April 2018, 21 $1^{\text {st }}$ April 2018, 22 ${ }^{\text {nd }}$ April 2018, 23 ${ }^{\text {rd }}$ April 2018. 